\title{
Analisis Potensi dan Strategi Pengembangann Pariwisata Berkelanjutan Berbasis Komunitas di Desa Sembungan, Wonosobo, Jawa Tengah
}

\author{
Sri Rahayu Budiani, Windarti Wahdaningrum, Dellamanda Yosky, Eline Kensari, Hendra S Pratama, Henny \\ Mulandari, Heru Taufiq Nur Iskandar, Mica Alphabettika, Novela Maharani, Rizka Fitria Febriani, Yanti Kusmiati
}

Fakultas Geografi, Universitas Gadjah Mada, Indonesia

Email Koresponden: srbudiani@yahoo.com

Diterima: Janurai 2018/Refisi: September 2018 Disetujui: September 2018

(๑) 2018 Fakultas Geografi UGM dan Ikatan Geograf Indonesia (IGI)

\begin{abstract}
Abstrak Desa Sembungan memiliki sumberdaya alam yang potensial, namun saat ini hanya dua objek wisata alam yang dikembangkan, yaitu Bukit Sikunir dan Telaga Cebong sehingga masih sangat mungkin untuk ditemukan objek wisata yang memiliki daya tarik. Oleh sebab itu, pemetaan di bidang pariwisata sangat bermanfaat untuk inventarisasi dan analisis potensi pariwisata di Desa Sembungan. Tujuan penelitian ini untuk melihat potensi, melakukan perencanaan dan Pengembangann pariwisata yang penting dilakukan di Desa Sembungan. Metode yang digunakan dalam penelitian ini, yaitu metode kualitatif dengan analisis deskriptif untuk mengidentifikasi dan mengeksplorasi potensi, Pengembangann, dan pengelolaan pariwisata di Desa Sembungan. Berdasarkan hasil penelitian diketahui Desa Sembungan memiliki potensi sumberdaya alam dan sumberdaya manusia sebagai daya tarik pariwisata. Desa Sembungan pada prinsipnya belum memenuhi prinsip pembangunan pariwisata berkelanjutan, sehingga perlu adanya pembenahan dari segi atraksi dan keunikan wisata, serta sumberdaya manusia. Dilihat dari tujuh prinsip pembangunan pariwisata berbasis komunitas, Desa Sembungan masih belum memenuhi tujuh prinsip tersebut, sehingga perlu Pengembangann pada aspek pelayanan dan akomodasi, promosi, Pengembangann industri dan pertanian, serta sarana transportasi.
\end{abstract}

Kata kunci : potensi wisata, pariwisata berkelanjutan, community based tourism.

Abstract Sembungan village has potential natural resources, but untill now only two natural tourism objects have been developed, namely Sikunir Hill and Cebong Lake. Hence, there are possibility/chance to find and make use of another potency. Therefore, mapping in the tourism sector is very useful for inventorying and analyzing tourism potential in Sembungan Village. The purpose of this research is to see the potential, planning, and developing important tourism in Sembungan Village. The method used in this research was a qualitative method with descriptive analysis to develop identified potency, and improve tourism management in Sembungan village. Based on the result, Sembungan village has the potential natural resource as a tourist attractiveness. Sembungan village has not yet manage tourism activities based on sustainable tourism principles. Accordingly, there are many aspects that need to be fixed of attractions, uniqueness of tourism, and human resources.. Tourism management also has not achieved the seven community-based tourism developments principles. Sembungan village still need to be fixed in the aspects of service and accomodation, promotion, industrial and agricultural development, as well as community transportation advice.

Keywords: tourism potentials, sustainable tourism, community based tourism

\section{PENDAHULUAN}

Pembangunan pariwisata saat ini diarahkan kepada pembangunan pariwisata yang berkelanjutan. Menurut Sharpley (2000) hal tersebut karena kebijakan pembangunan pariwisata berkelanjutan terarah pada penggunaan sumberdaya alam dan penggunaan sumberdaya manusia untukjangka waktu panjang. Salah satu desa wisata yang juga memiliki potensi dikelola dan dikembangkan berdasarkan prinsip-prinsip pariwisata berkelanjutan, yaitu Desa Wisata Sembungan, yang terletak di Kecamatan Kejajar, Kabupaten Wonosobo. Secara geografis, Desa Sembungan terletak pada $-7^{\circ} 13^{\prime} 31^{\prime \prime}$ dan $-7^{\circ} 15^{\prime} 19^{\prime \prime}$ garis lintang selatan (LS) serta $109^{\circ} 54^{\prime} 11^{\prime \prime}$ dan $109^{\circ} 55^{\prime} 47^{\prime \prime}$ garis bujur timur (BT).

Potensi pariwisata di Desa Sembungan masih perlu dikembangkan, mengingat destinasi wisata di desa tersebut merupakan destinasi favorit yang memiliki daya tarik wisata. Desa Sembungan memiliki sumberdaya alam yang potensial, namun saat ini hanya dua objek wisata alam yang dikembangkan, yaitu Bukit Sikunir dan Telaga Cebong sehingga masih sangat mungkin untuk ditemukan objek wisata yang memiliki daya tarik. Salah satu metode yang dapat digunakan untuk melihat potensi sekaligus untuk melakukan perencanaan dan Pengembangann pariwisata yang penting dilakukan, yaitu pemetaan objek wisata di Desa Sembungan.

Pemetaan dilakukan untuk mengetahui persebaran objek wisata yang memiliki daya tarik pariwisata, baik objek wisata yang sudah ada maupun yang potensial untuk dikembangkan dengan memperhatikan prinsip pembangunan berkelanjutan. Potensi wisata yang dimaksud dapat berupa sumberdaya alam yang beranekaragam dari aspek fisik dan hayati, serta kekayaan budaya manusia yang dapat dikembangkan sebagai atraksi pariwisata. Pemetaan di bidang 
pariwisata sangat bermanfaat untuk inventarisasi dan analisis potensi pariwisata. Hasil pemetaan yang ada kemudian akan menggambarkan kondisi dan karakteristik objek wisata.

Keberagaman jenis objek wisata dalam suatu kawasan wisata akan memiliki konsekuensi terhadap Pengembangann yang dominan di salah satu jenis objek wisata sehingga untuk mengetahui karakteristik objek wisata yang dominan dan potensial untuk dikembangkan dalam rangka mendukung pariwisata berkelanjutan digunakan analisis mengenai atribut wisata yang mengacu pada dokumen Sustainable Tourism yang dikembangkan oleh United Nations World Tourism Organization (UNWTO). Potensi Pengembangann pariwisata di Desa Sembungan sangat bergantung pada pengelolaan destinasi wisata yang ada.

Strategi yang paling gencar digunakan dalam Pengembangann pariwisata berkelanjutan salah satunya, yaitu Pengembangann yang didasarkan atas prinsip pemberdayaan berbasis masyarakat (Community Based Tourism). Konstruksi pariwisata berbasis masyarakat ini pada prinsipnya merupakan salah satu gagasan yang penting dan kritis dalam perkembangan teori pembangunan kepariwisataan konvensional (growth oriented model) yang seringkali mendapatkan banyak kritik karena telah mengabaikan hak dan meminggirkan masyarakat lokal dari kegiatan kepariwisataan di suatu destinasi (Rahayu, Sugi, 2015). Desa Wisata Sembungan merupakan salah satu destinasi yang juga dikembangkan dan dikelola secara mandiri oleh masyarakat setempat melalui Pokdarwis (kelompok sadar wisata).

Adanya Pokdarwis di Desa Sembungan menunjukkan bahwa desa wisata tersebut menerapkan konsep Community Based Tourism (CBT) dalam pengelolaan pariwisatanya. Namun demikian, meskipun pengelolaan pariwisata di Desa Sembungan mengembangkan potensi lokal tetapi Pengembangannnya hanya mengerucut pada potensi daya tarik fisik alam (sarana dan prasarananya), sementara pemberdayaan masyarakat dirasa masih belum optimal. Pengelolaan pariwisata Desa Sembungan lebih mempekerjakan masyarakat miskin, bukan memberdayakan masyarakat dan cenderung fokus kepada daya tarik wisata alam (Putri dan Manaf, 2013).

Berdasarkan latar belakang yang ada, penelitian ini bertujuan untuk memetakan potensi pariwisata Desa Sembungan sekaligus mengetahui bagaimana karakteristik pariwisata diDesa Sembungan berdasarkan indikator pariwisata berkelanjutan. Peneliti, selanjutnya juga ingin mengetahui apakah dengan adanya pariwisata berbasis CBT ini pengelolaan pariwisata akan lebih optimal serta memberikan keuntungan sosial dan ekonomi bagi masyarakat lokal sehingga dengan mengetahui persoalan tersebut nantinya akan diketahui arahan rekomendasi yang tepat yang dapat diberikan untuk mengelola destinasi wisata berbasis komunitas di Desa Sembungan.

\section{METODE PENELITIAN}

Desain penelitian ini menggunakan metode kualitatif. Analisis data penelitian menggunakan analisis deskriptif kualitatif. Data yang digunakan dalam penelitian ialah data kualitatif. Adapun data yang digunakan dalam penelitian ini disajikan dalam Tabel 1.

Tabel 1. Jenis dan Sumber Data

\begin{tabular}{|l|l|}
\hline \multicolumn{1}{|c|}{ Data } & \multicolumn{1}{|c|}{ Sumber Data } \\
\hline $\begin{array}{l}\text { Titik koordinat objek } \\
\text { wisata }\end{array}$ & Observasi lapangan \\
\hline $\begin{array}{l}\text { Foto Lanskap wilayah } \\
\text { Kajian }\end{array}$ & Observasi Lapangan \\
\hline Potensi objek pariwisata & $\begin{array}{l}\text { Observasi lapangan dan } \\
\text { Pokdarwis }\end{array}$ \\
\hline $\begin{array}{l}\text { Rencana Pengembangan } \\
\text { objek wisata dan kawasan } \\
\text { pariwisata }\end{array}$ & $\begin{array}{l}\text { Observasi lapangan dan } \\
\text { Pokdarwis }\end{array}$ \\
\hline $\begin{array}{l}\text { Pengelolaan dan atraksi } \\
\text { pariwisata }\end{array}$ & $\begin{array}{l}\text { Wawancara dan } \\
\text { Pokdarwis }\end{array}$ \\
\hline
\end{tabular}

Pengumpulan data dilakukan untuk data primer dan data sekunder. Teknik pengumpulan data primer dilakukan dengan dua cara, yaitu observasi lapangan dan wawancara. Teknik wawancara menggunakan wawancara mendalam dan wawancara terstruktur. Wawancara mendalam dilakukan dengan ketua Pokdarwis, Kepala Dinas Pariwisata Wonosobo, dan Kepala Bappeda Wonosobo. Wawancara terstruktur dilakukan kepada wisatawan dan masyarakat menggunakan teknik wawancara insidensial, sedangkan wawancara kepada pelaku industri dilakukan dengan teknik snow ball. Sementara pengumpulan data sekunder menggunakan studi literatur.

Teknik analisis data yang digunakan, yaitu analisis spasial dan analisis deskriptif kualitatif. Analisis spasial dilakukan berdasarkan pemetaan potensi wisata di Desa Sembungan untuk menjawab tujuan penelitian pertama. Sementara data dari hasil wawancara dianalisis secara deskriptif untuk menjawab tujuan penelitian kedua dan ketiga.

\section{HASIL DAN PEMBAHASAN}

\section{Potensi Objek Wisata di Desa Sembungan}

Potensi objek wisata Desa Sembungan memiliki daya tarik wisata yang hingga saat ini belum dikembangkan. Potensi wisata di Desa Sembungan, secara garis besar dapat dikelompokkan menjadi wisata alam, wisata buatan, wisata budaya, dan wisata edukasi. Masing-masing potensi memiliki keunikan dan ciri khas sebagai destinasi wisata.

Potensi wisata alam terdiri dari beberapa potensi objek wisata, diantaranya Bukit Sikunir, Telaga Cebong, Air Terjun Sikarim, dan Air Terjun Cilaka Sipendok. Potensi yang ada di Desa Sembungan selain potensi 
alam, yaitu potensi wisata buatan yang merupakan atraksi wisata yang dibuat dan ada untuk memberikan alternatif pilihan destinasi wisata di Desa Sembungan selain wisata berbasis alam. Beberapa lokasi yang berpotensi sebagai objek wisata buatan diantaranya rest area, gardu pandang, pasar wisata, dan home industry.

Penggunaan lahan dominan di Desa Sembungan adalah berupa lahan pertanian, selain itu keunggulan dari daerah ini adalah memiliki tanaman khas yang hanya dapat tumbuh di daerah dataran tinggi, yaitu tanaman Carica. Masifnya pertanian di Desa Sembungan tersebut merupakan potensi yang dapat dikembangkan sebagai kawasan agrowisata dan agroeduwisata. Potensi wisata budaya juga masih sangat mungkin untuk dikembangkan.

Kawasan wisata budaya merupakan atraksi wisata yang mengangkat kebudayaan masyarakat Desa Sembungan. Kebudayaan Desa Sembungan yang mampu menjadi atraksi seperti Tarian Ludrak, Tarian Imo-Imo, dan Ruwatan Rambut Gimbal serta wisata religi Makam Joko Sembung masih perlu dipromosikan sehingga atraksi wisata tidak terfokus hanya pada wisata alam serta mengangkat kembali kesenian tradisional yang belum banyak diketahui wisatawan.

Kekayaan potensi wisata Desa Sembungan perlu untuk diarah-kembangkan supaya dapat mendukung pariwisata berkelanjutan. Rekomendasi yang dapat diberikan untuk mengembangkan potensi wisata di Desa Sembungan diarahkan berdasarkan kondisi Desa Sembungan yang statusnya sebagai desa wisata, namun kondisi di lapangan belum mencerminkan demikian. Hal tersebut ditunjukkan dengan pengelolaan dan Pengembangann pariwisata yang masih terkonsentrasi pada Bukit Sikunir dan Telaga Cebong. Padahal Desa Sembungan memiliki banyak kenampakan alam dan tradisi budaya yang dapat diangkat sebagai atraksiatraksi wisata yang cukup menarik. Sebaran objek wisata yang potensial dikembangkan sebagai destinasi wisata ditunjukkan pada Gambar 1. Peta Kawasan dan Sebaran Objek Wisata Di Desa Sembungan (Lampiran 1).

\section{Karakteristik Pariwisata Berkelanjutan di Desa Sembungan}

Indikator pembangunan pariwisata berkelanjutan berdasarkan World Tourism Organization (UNWTO) berjumlah dua belas. Beberapa diantaranya berkaitan dengan aspek pembangunan sumberdaya manusia berjumlah enam indikator. Isu yang diangkat mulai dari keberlanjutan ekonomi, kesejahteraan masyarakat, keadilan sosial, ketenagakerjaan, kendali masyarakat lokal dalam pariwisata dan kemakmuran komunitas.

Indikator kunci tersebut memandang sektor pariwisata sebagai sumber dari upaya masyarakat dapat lepas dari garis kemiskinan. Kesejahteraan masyarakat, jati diri, kualitas hidup, nilai tambah dan konservasi sumberdaya seni serta budaya dan kerjasama internasional merupakan unsur-unsur kunci untuk mencapai visi pariwisata berkelanjutan Indonesia
(International Labour Organization, 2012). Indikator pariwisata berkelanjutan lainnya yang terkait aspek sumberdaya di Desa Sembungan, diantaranya indikator kekayaan budaya, integritas fisik, diversitas biologi, efisiensi sumberdaya, dan kemurnian lingkungan. Sumberdaya inti dalam pariwisata dibagi menjadi dua yaitu endowed (diwariskan) dan created (diciptakan).

Kompleksitas indikator pendukung pariwisata berkelanjutan membuat pembangunan tidak hanya difokuskan pada pembangunan infrastruktur fisik umum (Dawyer dan Kim, 2003), namun juga pada pembangunan sumberdaya manusia. Pembangunan manusia sebagai sumberdaya pendukung berperan sangat penting. Hasil lapangan dan wawancara dengan wisatawan, pelaku industri pariwisata, masyarakat Desa Sembungan, dan para pemangku kebijakan terkait pariwisata di Desa Sembungan menunjukkan perlunya banyak pembenahan dalam berbagai aspek untuk dapat mencapai pembangunan pariwisata yang berkelanjutan.

Sejauh ini, destinasi pariwisata Desa Sembungan masih bertumpu pada sumberdaya yang diwariskan, yaitu sumberdaya alam dan kebudayaan, sementara sumberdaya yang diciptakan dan pendukung masih belum dikembangkan dengan optimal. Wisatawan belum disuguhkan atraksi yang dapat menambah kepuasan berwisata. Padahal pemenuhan kepuasan pengunjung merupakan salah satu indikator pariwisata berkelanjutan.

Kepuasan pengunjung dapat dilihat daripemenuhan tiga prinsip pariwisata, yaitu something to see, something to do, dan something to buy. Aspek something to see dapat dipenuhi oleh sumberdaya yang diwariskan. Sementara aspek something to do dan something to buy berasal dari sumberdaya yang diciptakan dan sumberdaya pendukung.

Pengembangannaspeksomethingtododansomething to buy di Desa Sembungan perlu dikembangkan. Hal ini terkait dengan indikator kemurnian lingkungan supaya kualitas lingkungan dapat mendukung sektor pariwisata dalam rangka memenuhi kenyamanan pengunjung. Kenyamanan pengunjung berkaitan pula dengan pemenuhan kepuasan wisatawan.

Kurangnya kepuasan wisatawan yang berkunjung dan tidak adanya perkembangan destinasi wisata dapat menyebabkan kejenuhan. Pelayanan personal pariwisata merupakan salah satu kunci untuk meningkatkan volume wisatawan ke suatu daerah (Gretzel, et al., 2004). Terbatasnya atraksi dan fasilitas pendukung yang belum memadai dapat mengurangi perbandingan keuntungan destinasi wisata Desa Sembungan dengan destinasi wisata lainnya.

Berdasarkan analisis kedua belas indikator pariwisata berkelanjutan di Desa Sembungan dapat diketahui bahwa secara keseluruhan Desa Sembungan belum menerapkan prinsip pariwisata berkelanjutan. Pokok utama menuju pariwisata berkelanjutan yang harus dipenuhi adalah peningkatan kualitas 
sumberdaya manusia di Desa Sembungan agar dapat mengelola potensi sumberdaya yang ada secara optimal. Pemberdayaan masyarakat merupakan salah satu langkah penting dalam upaya untuk menciptakan pembangunan pariwisata berkelanjutan. Pengelolaan pariwisata, seperti sebuah bisnis agar mampu bertahan, pelatihan, dan pendidikan kepada tenaga kerjanya merupakan hal yang sangat penting (Zolfani, Sedaghat, Maknoon, \& Zavadskas, 2015). Kualitas sumberdaya manusia yang memadai akan sangat mendukung Pengembangann pariwisata di Desa Sembungan.

\section{Pengelolaan Pariwisata dan Arahan Pengembangann Pariwisata Berbasis Komunitas di Desa Sembungan}

Pengelolaan pariwisata berbasis komunitas merupakan suatu alat pembangunan dalam masyarakat guna meningkatkan peran masyarakat agar berpartisipasi aktif untuk mengelola pariwisata dan terlibat secara penuh dalam pengelolaan tersebut. Penilaian pengelolaan pariwisata berbasis komunitas di Desa Sembungan mengacu pada tujuh indikator yang menjadi dasar untuk mengetahui pengelolaan wisata berbasis komunitas (Keliwar, 2013), yaitu pengelolaan atraksi wisata, fasilitas, aksesibilitas, promosi, kemitraan, pemberdayaan masyarakat serta kondisi alam, sosial, ekonomi, dan budaya.

Pengelolaan atraksi pariwisata berbasis komunitas Desa Sembungan tergolong kurang optimal, hal ini disebabkan objek wisata yang beragam, kualitas sumberdaya alam yang baik, serta keunikan yang ada di Desa Sembungan kurang dikelola secara maksimal. Pengelolaan aksesibilitas masih tergolong kurang, karena jalan menuju objek wisata memiliki kondisi yang kurang baik dengan banyaknya jalan yang rusak dan sempit. Kondisi lingkungan Desa Sembungan dengan adanya pariwisata dapat dikatakan masih terjaga. Namun, sampah menjadi permasalahan dalam aspek lingkungan.

Kondisi Desa Sembungan selain dilihat dari lingkungannya juga dilihat dari kondisi ekonominya. Adanya pariwisata di Desa Sembungan ini terbukti berpengaruh terhadap kesempatan kerja dan pendapatan masyarakat. Hal ini sesuai dengan peran pariwisata sebagai pilar ekonomi (Kemenpar RI, 2015). Namun demikian masyarakat yang tidak terlibat dalam sektor pariwisata tidak mendapat pengaruh dari adanya industri pariwisata.

Masyarakat Desa Sembungan memiliki keramahan, sopan santun, dan budaya yang masih cukup baik. Budaya di Desa Sembungan masih cukup kental terlebih dengan adanya pariwisata, budaya yang ada menjadi hidup kembali meskipun belum cukup atraktif. Mekanisme kemitraan dalam pengelolaan pariwisata berbasis komunitas di Desa Sembungan tergolong masih kurang. Belum ada sinergitas dan kerjasama antar pemangku kebijakan, baik dari perencana maupun Pengembangann. Pemberdayaan masyarakat di Desa Sembungan dalam pariwisata juga tergolong kurang optimal. Hal tersebut karena belum banyak melibatkan masyarakat dalam pengelolaan pariwisata, seperti perencanaan dan pelaksanaan pariwisata. Uraian mengenai tujuh indikator yang menjadi dasar untuk mengetahui pengelolaan wisata berbasis komunitas di Desa Sembungan tersebut juga disajikan dalam Tabel 1. Pengelolaan Pariwisata di Desa Sembungan (Lampiran 2). Berdasarkan uraian tersebut maka dapat dikatakan bahwa pengelolaan pariwisata belum memenuhi tujuh prinsip community based tourism.

Pengelolaan pariwisata di Desa Sembungan agar dapat mewujudkan pariwisata berkelanjutan berbasis pemberdayaan masyarakat perlu memerhatikan beberapa aspek, terutama Pengembangann sumberdaya manusia yang perlu dikembangkan untuk mendukung pariwisata berbasis komunitas di Desa Sembungan untuk menyediakan pelayanan dan akomodasi, promosi, Pengembangann industri dan pertanian, serta sarana transportasi. Hal ini karena pada dasarnya Desa Sembungan memiliki kekuatan pada kekayaan atraksi wisata yang masih bisa dikembangkan menjadi pariwisata yang berdaya saing. Adapun arahan rekomendasi yang diberikan berupa pengelompokan kawasan yang disesuaikan dengan kondisi lingkungan yang ada seperti ditunjukkan dalam Gambar 1. Peta Kawasan dan Sebaran Objek Wisata Di Desa Sembungan (Lampiran 1)

Pengembangann pada aspek pelayanan dan akomodasi di Desa Sembungan ditekankan pada pengelolaan penginapan aktif (homestay). Hal ini karena masyarakat yang memiliki penginapan masih kurang memahami pengelolaan penginapan yang kreatif dan belum memiliki standar pelayanan, sehingga perlu adanya program Pengembangann penginapan yang mengusungkonsep satu pintu (konsorsium) agar seluruh penginapan yang ada di Desa Sembungan terorganisir dengan baik. Pengembangann ini diarahkan pada zonasi yang sesuai peruntukannya, yaitu pada zonasi kawasan wisata buatan maupun kawasan wisata budaya. Hal ini karena kondisi lingkungan yang mendukung, seperti banyaknya permukiman penduduk, pusat aktivitas budaya, dan pusat strategis ekonomi.

Arahan rekomendasi kedua, yaitu perlu adanya layanan informasi untuk wisatawan. Masyarakat dan Pokdarwis perlu menyediakan jasa pemandu wisata yang memiliki keterampilan dan kompetensi dalam satu pengelolaan di pusat informasi. Prinsip pariwisata yaitu memenuhi tiga kriteria, yaitu something to see, something to buy, dan something to do (Yoeti, Oka A, 1996). Namun di Desa Sembungan sendiri hanya mengembangkan prinsip something to see. Sehingga dalam grand desain pariwisata dikembangkan something to buy, dan something to do. Apabila kedua hal tersebut sudah dapat dijalankan, maka sebaiknya retribusi masuk dikurangi atau dihapus, sebagai gantinya adalah memasukan pajak sebagai tanggungan wisatawan dalam menikmati atraksi/jasa pariwisata, 
dan membentuk UMKM dibawah BUMDES untuk memenuhi kebutuhan something to buy bagi wisatawan untuk meningkatkan pendapatan masyarakat. Zonasi yang dapat diperuntukkan sebagai kawasan Pengembangann industri dalam rangka mendukung terpenuhinya prinsip pariwisata, yaitu kawasan wisata buatan yang saat ini memang sudah diperuntukkan sebagai pasar wisata dan kawasan wisata budaya yang saat ini juga sudah tersedia industri rumahan dan pusat oleh-oleh (lihat Lampiran 1).

Aspek promosi juga perlu dikembangkan agar pariwisata di Desa Sembungan dapat dikenal masyarakat luas dan kedepannya pariwisata menjadi ramai. Rekomendasi yang dapat diusulkan, yaitu dengan meningkatkan promosi wisata dan meningkatkan sistem informasi berbasis digital. Upaya lain yang juga dapat dilakukan, yaitu membuat paket wisata khusus Desa Sembungan, mengadakan kerjasama dengan biro jasa dalam mempromosikan pariwisata, dan penggunaan web design maupun sosial media untuk media promosi. Hal ini penting dilakukan, mengingat atraksi wisata terutama atraksi budaya masih belum dipromosikan dengan optimal.

Pengembangann industri dan pertanian juga diperlukan agar semua masyarakat Desa Sembungan ikut menikmati dampak dari adanya pariwisata, bukan hanya masyarakat yang terlibat dalam sektor pariwisata tetapi petani dan pelaku industri juga mendapatkan keuntungannya. Rekomendasi yang dapat dilakukan yaitumendorongmasyarakat untukmenciptakan inovasi kreatif dalam Pengembangann kawasan agrowisata maupun kawasan agroeduwisata (lihat Lampiran 1). Hal ini dimaksudkan juga untuk memberdayakan masyarakat dan memenuhi prinsip pariwisata something to buy. Program yang dapat dilakukan yaitu dengan mengadakan pelatihan masyarakat untuk mengembangkan inovasi hasil produksi pertanian dan mengadakan pelatihan keterampilan masyarakat untuk menghasilkan souvenir khas Desa Sembungan. Hal ini mengingat pula bahwa Desa Sembungan merupakan Desa yang memiliki tanaman khas daerah dataran tinggi, yaitu tanaman Carica selain juga tanaman kentang yang memiliki nilai jual tinggi. Lokasi yang baik untuk Pengembangann industri, yaitu lokasi yang saat ini banyak dijadikan pusat oleh-oleh dimana lokasi tersebut dekat dengan permukiman penduduk (lihat Lampiran 1).

Sarana transportasi menuju tempat wisata di Desa Sembungan masih perlu adanya perbaikan. Perlu adanya pengelolaan transportasi dari tempat parkir (lihat lampiran 1) menuju ke tempat wisata dan meningkatkan aksesibilitas dari segi transportasi. Hal ini diperlukan agar wisatawan menjadi nyaman dan dengan mudahnya akses dapat meningkatkan jumlah wisatawan. Program yang dapat dilakukan adalah dengan membentuk kelompok yang menaungi driver settle. Kelompok ini diharapkan dapat mengelola transportasi dengan lebih baik lagi.
Upaya untuk mewujudkan pariwisata berkelanjutan berbasis komunitas di Desa Sembungan perlu memerhatikan kerjasama antar pihak, diantaranya masyarakat, Pokdarwis, dan pemerintah sehingga diharapkan Pengembangann pariwisata Desa Sembungan menjadi lebih terarah. Adanya arahan rekomendasi diharapkan mampu menjadikan Desa Sembungan menjadi desa wisata yang memiliki daya saing pariwisata.

\section{KESIMPULAN}

Potensi objek wisata Desa Sembungan memiliki daya tarik wisata yang hingga saat ini belum dikembangkan. Potensi wisata yang ada selain Telaga Cebong dan Bukit Sikunir, yaitu Camping Ground Telaga Cebong, Air Terjun Sikarim, Air Terjun Cilaka Sipendok, dan Wisata Tracking Gunungapi Pakuwojo, agroedutourism dan agrotourism, wisata makam Joko Sembung, gardu pandang, Tari Imo-imo dan Tarian Ludrak serta Adat Ruwatan Rambut Gimbal, serta pasar wisata dan industri rumahan.

Karakteristik pariwisata berdasarkan indikator pariwisata berkelanjutan di Desa Sembungan menunjukkan perlunya banyak pembenahan untuk dapat mencapai pembangunan pariwisata yang berkelanjutan. Diantaranya dilihat dari segi atraksi wisata dan keunikan wisata, serta sumberdaya manusia.

Pengelolaan pariwisata di Desa Sembungan masih kurang optimal. Terdapat Beberapa aspek, terutama Pengembangann sumberdaya manusia yang perlu diarah-kembangkan untuk mendukung pariwisata berbasis komunitas di Desa Sembungan, antara lain aspek pelayanan dan akomodasi, promosi, Pengembangann industri dan pertanian, serta sarana transportasi.

\section{UCAPAN TERIMA KASIH}

Penulis mengucapkan terima kasih kepada Pokdarwis Desa Sembungan dan mahasiswa KKL 3 Geografi Lingkungan, Fakultas Geografi UGM yang telah membantu terlaksananya penelitian ini serta memberi dukungan finansial terhadap penelitian ini.

\section{DAFTAR PUSTAKA}

Dwyer, L., \& Kim, C. W. (2003). Destination competitiveness: Determinants and indicators. Current Issues in Tourism.

Gretzel, U., Mitsche, N., Hwang, Y. H., \& Fesenmaier, D. R. (2004). Tell me who you are and I will tell you where to go: Use of travel personalities in destination recommendation systems. Information Technology \& Tourism, 7(1), 3-12.

International Labour Organization. (2012). Rencana Strategis Pariwisata Berkelanjutan dan Green Jobs untuk Indonesia. Jakarta: ILO Country Office Jakarta. 
Keliwar, S. (2013). Pola Pengelolaan Ekowisata Berbasia Komunitas di Taman Nasional Gunung Halimun Salak. Jurnal Nasional Pariwisata, Vol. 5 No. 2.

Kementerian Pariwisata Republik Indonesia. (2015). Lampiran Peraturan Menteri Pariwisata Republik Indonesia Nomor 29 Tahun 2015 Tentang Rencana Strategis Kementerian Pariwisata Tahun 20152019. Jakarta: Kemenpar RI

Putri, H.P.J.P dan Manaf, A. (2013). Faktor-Faktor Keberhasilan Pengembangann Desa Wisata di Dataran Tinggi Dieng. Jurnal Teknik PWK, Vol. 2 No. 3

Rahayu, Sugi. (2015). Pengembangann Pariwisata Berbasis Masyarakat (Community Based Tourism) di Kabupaten Kulon Progo Daerah Istimewa Yogyakarta. Laporan Penelitian Hibah Bersaing.
Universitas Negeri Yogyakarta.

Sharpley, R. (2000). Tourism and Sustainable Development: Exploring the Theoretical Divice. Journal of Sustainable Tourism, VIII (1): 1-19

WTO. (2001). The Concept of Sustainable Tourism.http:// www.worldtourism.org/sustainable/concepts.htm.

Yoeti, Oka A. (1996). Pengantar Ilmu Pariwisata. Bandung: Angkasa.

Zolfani, S. H., Sedaghat, M., Maknoon, R., \& Zavadskas, E. K. (2015). Sustainable tourism: A comprehensive literature review on frameworks and applications. Economic Research-Ekonomska Istrazivanja, 28(1), 1-30. https://doi.org/10.1080/1331677X.2014.9958 95

\section{LAMPIRAN}

\section{Lampiran 1}

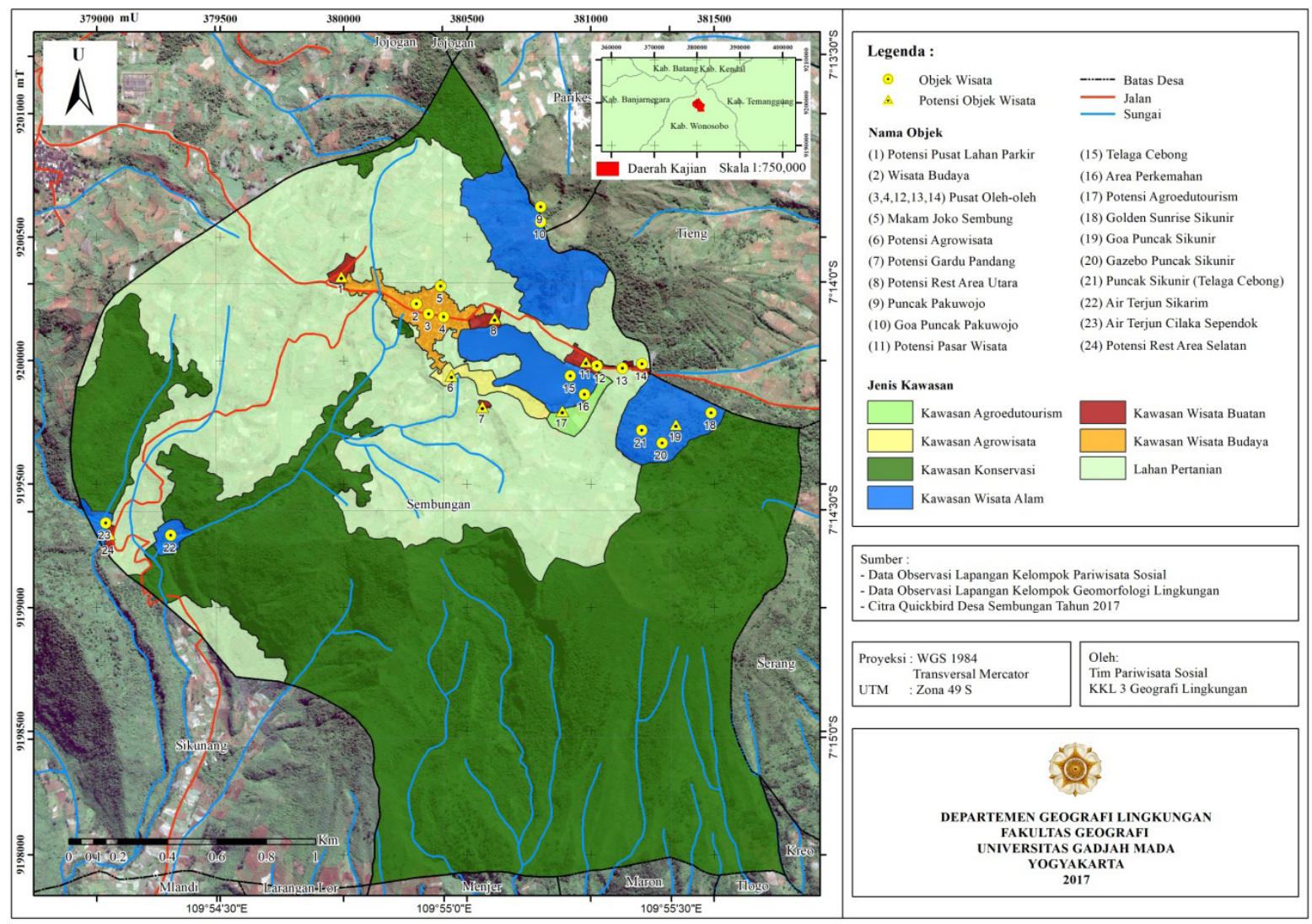

Gambar 1. Peta Kawasan dan Sebaran Objek Wisata Di Desa Sembungan 


\section{Lampiran 2.}

Tabel 1. Pengelolaan Pariwisata di Desa Sembungan

\begin{tabular}{|c|c|c|}
\hline No. & Variabel & Kondisi \\
\hline 1. & $\begin{array}{l}\text { Mekanisme pengelolaan atraksi } \\
\text { pariwisata berbasis komunitas }\end{array}$ & $\begin{array}{l}\text { Pengelolaan atraksi pariwisata berbasis komunitas masih belum } \\
\text { optimal }\end{array}$ \\
\hline 2. & $\begin{array}{l}\text { Mekanisme pengelolaan fasilitas } \\
\text { pariwisata berbasis komunitas }\end{array}$ & $\begin{array}{l}\text { Pengelolaan fasilitas penunjang kebutuhan wisatawan sudah cukup } \\
\text { baik, namun perlu penambahan fasilitas seperti ruang terbuka } \\
\text { hijau, rest area, gazebo, dan handrail }\end{array}$ \\
\hline 3. & Mekanisme pengelolaan aksesibilitas & $\begin{array}{l}\text { Pengelolaan fasilitas masih kurang. Aksesibilitas tinggi, namun } \\
\text { kondisi jalan menuju objek wisata kurang. Terdapat banyak jalan } \\
\text { yang rusak dan terlalu sempit. }\end{array}$ \\
\hline 4. & $\begin{array}{l}\text { Kondisi lingkungan, ekonomi, dan } \\
\text { sosial-budaya }\end{array}$ & $\begin{array}{l}\text { 1. Lingkungan sedang diusahakan untuk diperbaiki dengan } \\
\text { program bank sampah }\end{array}$ \\
\hline & & $\begin{array}{l}\text { 2. Adanya pariwisata dapat membuka lapangan pekerjaan dan } \\
\text { meningkatkan pendapatan masyarakat }\end{array}$ \\
\hline & & $\begin{array}{l}\text { 3. Masyarakat ramah, menjaga sopan santun, budaya dan adat } \\
\text { istiadat Budaya di Desa Sembungan: Ruwat rambut gembel, } \\
\text { tarian ludrak dan imo-imo. Wisatawan tidak mengetahui budaya } \\
\text { yang ada di Desa Sembungan }\end{array}$ \\
\hline 5. & $\begin{array}{l}\text { Mekanisme promosi pariwisata } \\
\text { berbasis komunitas }\end{array}$ & $\begin{array}{l}\text { Promosi pariwisata masih sangat kurang. Hal ini karena belum ada } \\
\text { pengelolaan media promosi secara masif, belum ada paket wisata } \\
\text { khusus Desa Sembungan }\end{array}$ \\
\hline 6. & $\begin{array}{l}\text { Mekanisme kemitraan, dalam } \\
\text { pengelolaan pariwisata berbasis } \\
\text { komunitas di Sembungan }\end{array}$ & $\begin{array}{l}\text { Kemitraan dalam pengelolaan pariwisata masih kurang. Hal } \\
\text { ini karena belum ada sinergitas dan kerjasama antar pemangku } \\
\text { kebijakan, baik dari perencanaa maupun Pengembangann. }\end{array}$ \\
\hline 7. & $\begin{array}{l}\text { Pemberdayaan masyarakat desa } \\
\text { Sembungan melalui pariwisata }\end{array}$ & $\begin{array}{l}\text { Pemberdayaan masyarakat belum optimal. Hal ini karena } \\
\text { belum banyak melibatkan masyarakat dalam merencanakan, } \\
\text { dan pelaksanaan pariwisata, sehingga masyarakat belum semua } \\
\text { merasakan dampak pariwisata. }\end{array}$ \\
\hline
\end{tabular}

Sumber: Olah data lapangan (Tim Pariwisata Sosial KKL 3, 2017) 